Article

\title{
Proving Their Worth? The Transatlantic Trade and Investment Partnership and the Members of the European Parliament
}

\author{
Guri Rosén \\ ARENA Centre for European Studies, University of Oslo, 0318 Oslo, Norway; E-Mail: guri.rosen@arena.uio.no
}

Submitted: 14 May 2019 | Accepted: 26 August 2019 | Published: 27 September 2019

\begin{abstract}
Recent trade negotiations in the EU have provoked unprecedented levels of controversy, in particular the Transatlantic Trade and Investment Partnership (TTIP) between the EU and the US. One crucial channel for public contestation is the European Parliament (EP) which, following the entry into force of the Lisbon Treaty, has to give consent to international agreements. Thus, this article sets out to answer the question: During the dispute over TTIP, did members of the EP (MEPS) engage in the public debate, and if so, how? If they engage in debates, what characterises their engagement: Do they engage with voter concerns, do they engage in a responsive manner, and do they contribute to politicisation as quite a few feared? Building on an analysis of newspaper coverage and plenary debates in the EP, the article shows that many supporters of TTIP attempted to de-politicise the debate, while opponents most frequently evoked 'the voice of the people' to politicise TTIP. Thus, MEPs do not only respond to politicisation, they also attempt to make politicisation happen by evoking public concerns. The article highlights the multifaceted relationship between responsiveness and politicisation, where claims responding to voter concerns, are used both to incite contestation and alleviate it.
\end{abstract}

\section{Keywords}

European Parliament; European Union; parliamentarisation; politicisation; responsiveness; trade policy; Transatlantic Trade and Investment Partnership

\section{Issue}

This article is part of the issue "Out of the Shadows, Into the Limelight: Parliaments and Politicisation", edited by Christine Neuhold (Maastricht University, The Netherlands) and Guri Rosén (University of Oslo, Norway).

(C) 2019 by the author; licensee Cogitatio (Lisbon, Portugal). This article is licensed under a Creative Commons Attribution 4.0 International License (CC BY).

\section{Introduction}

Recent trade negotiations in the EU have provoked unprecedented levels of controversy. Particularly the Transatlantic Trade and Investment Partnership (TTIP) between the EU and the US became divisive. Had the negotiations not faltered, the agreement would have been one of the largest free trade agreement in history, and according to its advocates, have led to job creation and a general increase in living standards on both sides of the Atlantic. With TTIP, however, EU trade policy "went from being contested amongst a relatively small group of actors largely out of public view to being actively challenged in the public sphere" (Young, 2019).

One channel for public contestation is the European Parliament (EP) which, following the entry into force of the Lisbon Treaty, has to consent to international agreements. Members of the European Parliament (MEPs) are now in a position to defeat EU trade deals, even against the wishes of member states and before national parliaments get to weigh in. EU trade policy has always been a carefully constructed compromise between member state positions that often collide. With the EP's new powers, the risk is that the difficulty of forging a common position in the EU increases, because the Commission has to cater to even more principals (da Conceição-Heldt \& Meunier, 2014). It is perhaps not surprising that a main argument against extending the powers of the EP in trade was that it would politicise debates on trade agreements and legislation, making it even more disruptive (Niemann, 2011; Woolcock, 2008). Against this background - the broad contestation of TTIP, the EP's 
new powers, and the fears of its unruliness-, the question raised in this article is: During the dispute over TTIP, did MEPs engage in the public debate, and if so, how?

Following large parts of the literature, one would not expect MEPs to engage extensively. A prevalent view is that their link with voters is weak due to the way "EP elections (do not) work" (Hix, Raunio, \& Scully, 2003, p. 194). Instead of responding to voter preferences, MEPs' main principals are the national parties, who select the candidates in EP elections, and the supranational party groups, who control the internal affairs of the EP (Hix, 2002, p. 688). TTIP became a difficult issue for the EP, and particularly so for some of its political groups. The plenary was supposed to decide on recommendations to the Commission in June 2015, but ended up postponing the vote, officially because there were too many amendments tabled. Furthermore, as a newcomer to the field of trade, it is conceivable that the EP would like to appear as a responsible actor and refrain from conflict with the Council or Commission (cf. Ripoll Servent, 2013). As elected representatives, MEPs should pay heed to the concerns of their voters, but at the same time the majority of members in the EP wanted to see the talks succeed and has encouraged member states to make a better effort at selling it to their respective citizens (EP, 2015a).

At the same time, in the case of the Anti-Counterfeit Trade Agreement, where the EP vetoed a trade agreement for the first time, MEPs allegedly reacted to civil society pressure and public protests (Dür \& Mateo, 2014), challenging the view of non-responsive MEPs. International trade is an issue where MEPs can claim ownership and are in a favourable position both to monitor and impact negotiations. Consequently, trade should be a good occasion for MEPs to demonstrate their importance. By analysing debates taking place in national media as well as in the EP plenary, the aim of this article is to get a better understanding of the role of the EP in salient policies. To what extent do they engage in debates, and when they do, what characterises their engagement: Do they engage with voter concerns; do they engage in a responsive manner; and do they contribute to politicisation as feared? While we know quite a lot about the EP's interinstitutional activities in the case of both trade and TTIP (e.g., Coremans \& Meissner, 2018; Meissner, 2016), we know less about how MEPs engage with public debate. Thus, by focusing on how they approach voters and their concerns, this article can also shed light on the relationship between MEPs and EU citizens. In addition, through studying the engagement of MEPs in the TTIP debate, the aim is also to explore the relationship between responsiveness and politicisation.

In what follows, the analytical framework and ensuing expectations are elaborated, before the subsequent section presents the data and method used in the article. The first part of the analysis briefly assesses the levels of salience in three selected countries, while the second part looks at what characterises the engagement of
MEPs. The conclusion suggests some empirical and theoretical implications of the findings.

\section{Linking Controversy and MEPs' Engagement}

Central components of the electoral relationship are the acts of authorisation and opportunity to hold elected representatives to account (Pitkin, 1967). Before elections, aspiring candidates are eager to establish that they have done a good job in office and to convince their electorate that they will do a better job than their opponents. Aspiring parliamentarians make great efforts to reach potential voters with their message. In-between elections more attention is directed towards internal processes of policy-making. Deals are made and interests brokered behind closed doors, or at least removed from the glare and stare of the public.

Some policy issues, however, attract substantial attention and stimulate a wider public debate. Such instances of issue salience or contestation require that politicians somehow address voters' concerns (e.g., Wlezien \& Soroka, 2012). If an issue becomes important in public debate-if it engages mass politics (Hooghe \& Marks, 2009) - the cost of ignoring the 'voice of the people' increases. Thus, issue salience has "developed into one of the leading theories of political communication and political party behaviour" (Budge, 2015, p. 761). Research shows that EU policies are affected by public opinion (e.g., Bølstad, 2015; Rauh, 2019; Toshkov, 2011). De Bruycker (2017) also demonstrates how issues that are salient generate more responses referring to public interest compared to non-salient ones. Others describe how parliamentarians tend to get more engaged in issues that are important to the public (Baumann, Debus, \& Gross, 2019), including matters of the EU (e.g., Auel, Rozenberg, \& Tacea, 2015; Gheyle, 2019b).

Issue salience has been described a critical denominator of politicisation (Green-Pedersen, 2012; Hoeglinger, 2016), which denotes "an increase in the polarization of opinions, interests or values and the extent to which they are publicly advanced towards the process of policy formation within the EU" (de Wilde, 2011, p. 560). In the words of Hutter and Grande (2014, p. 1004): "Only topics that are frequently raised by political actors in public debates can be considered politicized." However, politicisation denotes something more than salience in that it entails the "expansion of the scope of conflict within the political system" (Hutter \& Grande, 2014, p. 1003). An issue can be salient-achieve a lot of attention in the news media for example-but if it does not engage a broader set of actors or provokes contestation, it suggests that the conflict does not run very deep (see Gheyle, 2019a).

On the one hand, politicians in general are keen to "'rid[e] the wave' of prominent issues because they want to appear responsive to public concerns" (Hoeglinger, 2016 , p. 49). On the other hand, they might want to add 'fuel to the flame' in order to attract attention to 
their own policies, gain support for their own position, or play havoc with their opponents. When an issue-such as TTIP-becomes increasingly salient, MEPs can get engaged in various ways, whether in response to or as an attempt to instigate contestation. Furthermore, responsiveness can also involve attempts to politicise an issue, hence responsiveness and mobilisation are not mutually exclusive. However, the implications for EU trade policy, as well as for our understanding of the role of MEPs in public debate and salient politics will differ.

In addition, one could argue that by getting engaged or acting responsively, MEPs contribute to politicisation, even if not in a pro-active manner. Gheyle (2019a), for example, claims in this thematic issue that parliamentarisation - the communicative behaviour of parliamentarians-should be seen as a component of politicisation. This obviously makes the establishment of causal links difficult. The aim of this article, therefore, is to explore the relationships between issue salience and the role of MEPs, as well as between responsiveness and politicisation.

First, the goal is to see if MEPs engaged with the TTIP debate. As described above, large parts of the literature lead us to expect that the relationship between MEPs and EU citizens is fraught. The subsequent question is whether this putative engagement is responsive in the sense that it aims to accommodate the concerns of citizens. Again, due to the lack of an electoral linkage, and MEPs having to accommodate two principals, there is a certain expectation that MEPs will not be responsive. Finally, the aim is to analyse if and how MEPs responded in a manner that could be seen as contributing to the politicisation of the agreement. The empowerment of the EP in trade caused fears that the trade policy would become more unruly because the EP would politicise the field ${ }^{1}$. Moreover, an issue might be salient without being politicised, which is why this article aims to investigate whether and how MEPs sought to expand the political conflict in the case of TTIP.

\subsection{Engagement}

There is an increasing interest in to what extent and how national parliaments contribute to the politicisation of European governance (see for instance Bellamy \& Kröger, 2016). The specific participation of MEPs in national media debates has thus far received less attention. A general impression is that during election campaigns, EU actors take the backseat, while national parties run the show (de Vreese, Banducci, Semetko, \& Boomgaarden, 2006). EU-related issues reach the media if national parties decide to make it a priority (Jalali \& Silva, 2011, quoted in Adam \& Maier, 2011, p. 433). The few studies that have looked specifically at the EP's performance in the news, find that it does receive regular coverage (Gattermann, 2013), but that journalists tend to take a domestic per- spective, even when they report on the EP (Gattermann \& Vasilopoulou, 2015, p. 134).

TTIP, however, was an issue where the MEPs could potentially claim ownership to a greater extent. Although the agreement most likely would have to be ratified by national parliaments as well, MEPs were in a favourable position to monitor-and have an impact on-the talks between the EU and the US. At the outset of the talks, national parliamentarians had great difficulties accessing the necessary documents to monitor the TTIP negotiations. The EP, by contrast, was highly successful in pushing for access to confidential documents for all MEPs (Rosén, 2018). Thus, in contrast to EP elections, or policy debates where the EP plays a more marginal role, one could argue that TTIP was a good occasion for MEPs to demonstrate their importance without too much competition. MEPs are not only dependent on the good will of their voters for re-election, but crucially also on their national parties, who control the nomination processes (Hix, 2002). Having to cater to several principals, means that MEPs do not only face the pressure from the public when a policy is salient, but also from their national colleagues. Studies of voting instructions to MEPs by national parties, for example, have shown that these are not very common (Mühlböck, 2012), and mainly given when an issue is held to be of "fundamental importance" (Raunio, 2000, p. 217). This leads to two different expectations:

MEPs have a high level of engagement on TTIP;

MEPs from countries where TTIP is salient have a lower level of engagement.

\subsection{Responsiveness}

The subsequent question is how MEPs engaged, if at all, in debates about TTIP. It has been argued that the relationship between MEPs and voters tends to be ignored due to "widely held assumptions that any electoral connection to the EP is weak because of the way EP elections (do not) work" (Hix et al., 2003, p. 194). Hix, Noury, and Roland (2007, p. 28) have argued that because MEPs lack the external motivation of re-election, "political behaviour in the European Parliament is primarily driven by considerations internal to the institution and the EU policy process." Thus, the contestation over EU trade policy could be argued to leave MEPs with a dilemma, as they have to adjudicate between their commitments to their national party, their EP party group, as well as their voters.

But even if the electoral connection might be weak, this is not the same as saying that it is non-existent, or that the EP and its MEPs are content with the apparent lack of an electoral link. Elections are not the only reason why representatives are responsive to their constituents. A sense of duty may compel politicians to take the in-

\footnotetext{
${ }^{1}$ In this thematic issue, Zimmermann (2019) puts forward the concept of "layered politicisation" to depict policies that are not fully politicised. He describes the case of EU fisheries policy, where there is polarisation and mobilisation, but low issue salience.
} 
terests of their constituency into account. In addition, it is likely that both are influenced by the same objective events (cf. Bartels, 1991, p. 458). Thus, it is reasonable to assume that MEPs will attempt to respond to the concerns of EU citizens even if they don't have to fear their judgement come election time.

We know less about how MEPs relate to EU citizens in-between elections, as the bulk of research on EU parliamentary democracy has concentrated on EU elections. Key to studies that analyse the interaction between representatives and citizens is responsiveness, which is held to be the mechanism that maintains the representative relationship in-between elections (Esaiasson \& Narud, 2013). A main indicator of responsive behaviour is policy adaption. This is the ultimate sign that representatives are acting on behalf of their electorate. According to Manin, Przeworski, and Stokes (1999, p. 9), to be responsive equals adopting policies that citizens prefer. Adaption can also be presented communicatively through promises-Hobolt and Klemmensen (2008, p. 310) use the term "rhetorical responsiveness" for example. This concept captures the extent to which the political issue agenda "reflects the issue most salient to the public" (Hobolt \& Klemmensen, 2008, p. 320).

Yet, representatives are not always ready, or able, to adapt to citizens' preferences. There are also ways of responding where representatives do not necessarily take on-board positions of citizens. However, it is crucial that representatives "must not be found persistently at odds with the wishes of the represented without good reason in terms of their interest, without a good explanation of why their wishes are not in accord with their interest" (Pitkin, 1967, pp. 209-210). If representatives are not prepared to adapt to citizens' preferences, they will have to give reasons for why a decision is beneficial even if it might also cause problems. Without attempting to justify their positions in cases where representatives act against citizens' preferences, it is unlikely that their positions will be seen as legitimate, as justification is central to the democratic legitimacy of decisions (Lord, 2013).

One option for politicians is that they explain their views, i.e., account for the reasons they do not act in accordance with citizens' preferences (Esaiasson, Gilljam, \& Persson, 2013). Grose, Malhotra, and van Houweling (2015, p. 725), for example, argue that representatives tend to use "tailored explanations in order to compensate for policy choices that are incongruent with constituent preferences, and to reinforce policy choices congruent with constituent preferences." To alleviate accusations of ignorance, politicians may also signal that they are listening, which would demonstrate that they are aware of citizens' concerns. Furthermore, 'listening' has been shown to have a significant effect on citizens' evaluation of policy decisions (Esaiasson, Gilljam, \& Persson, 2017).

But if they acted in a responsive manner, what type of responses did MEPs offer their European constituents in the case of TTIP? Drawing on the literature on com- municative responsiveness (Esaiasson et al., 2013; Grose et al., 2015; Hobolt \& Klemmensen, 2008), this article differentiates between three forms of communicative responses: promises to adapt to public opinion; signalling by parliamentarians that they listen to public concerns; and explanations-justifications-for positions or decisions.

Previous studies have demonstrated that the EP tends to present more moderate demands when it acquires more powers (Ripoll Servent, 2013). When more is at stake, the EP becomes more concerned with "doing good" in institutional terms. In other words, it eases the pressure in legislative processes to "enhance its reputation as a reliable legislative partner" (Burns \& Carter, 2010, p. 132). First of all, with lower levels of salience, there is less of an audience to respond to. A second possible reason is that MEPs might want to keep the discussion with the executive free from public interference. Finally, making promises could prove futile in a situation of on-going negotiations. Thus, with lower levels of salience one could expect MEPs to rely on 'softer' forms of responsiveness, such as signals that they are listening to public concerns. When salience increases, however, one would assume that it puts pressure on parliamentarians to provide more substantive responses. If MEPs are to prove their worth to the European citizenry, one would expect them to amplify their efforts when their audiences grow, by justifying their position or making promises about future choices:

With higher levels of salience, more MEPs make promises and offer explanations.

\subsection{Contribution to Politicisation}

While it is reasonable to assume that MEPs are more likely to want to appear responsive when they know that an issue is salient to a large public, politicians do not merely react to the political mood, they also try to steer it. Public pressure can be used as leverage in policy-making processes, which means that there is an incentive for politicians to mobilise public opinion to their support. In other words, politicians may contribute pro-actively to the politicisation of an issue by performing the "role of articulating an initial plurality of opinions within society on issues related to the EU, into a more focused and coherent set of claims on policy" (de Wilde, 2011, p. 564). In the case of TTIP, MEPs could have contributed to politicising an already salient issue by encouraging contestation (cf. Adam \& Maier, 2011) or by expanding the scope of actors-for example if they put forward their views in collaboration with, or on behalf of, civil society actors. De Bruycker (2017) has demonstrated that governments' responsiveness increases when an issue is salient or when civil society mobilises, while polarisation has little effect on levels of responsiveness. In this article, however, the aim is to see whether and how responsiveness is part of the process of politicisation. If and when MEPs 
claim to listen to concerns, make promises, or offer explanations for their position, they may also contribute to politicisation of TTIP by contesting the agreement or by evoking other actors. More salient policy issues have a higher conflict potential, which makes strategic efforts to politicise them more likely (cf. Adam \& Maier, 2011; Baumann et al., 2019):

With higher levels of salience, more MEPs seek to contribute to politicisation.

The following section describes how the four expectations are investigated.

\section{Data and Method}

The sources of data in this article are newspaper articles reporting on TTIP and plenary debates in the EP. To the average citizen, media is the key access point for political communication. Moreover, it is a key area for contestation:

Although it is not the only forum, or form, of public debate, the mass media is crucial, because it is where the general public can gain access to information about executive decision making and the stances of political actors who challenge decisions. (Statham \& Trenz, 2015, pp. 291-292)

At the same time, because MEPs are not free to determine their response through the media, plenary debates about TTIP are used to access 'un-filtered' statements.

Surveys show that the majority of Europeans are favourably disposed to a trade and investment agreement between the EU and the US, but there are also substantial variations between member states. Germans and Austrians are by far the most sceptical, while countries such as France, Sweden and the UK have displayed a solid majority in favour of the agreement (European Commission, 2014, 2015, 2016). There are also variations in how engaged citizens are across Europe. In the Commission's public consultation on the investor state dispute settlement (ISDS) mechanism, 79\% of the submissions where from Austria, the UK and Germany, and there is a similar pattern for the European Citizens' Initiative on TTIP (de Ville \& Siles-Brügge, 2015). Based on public opinion surveys and patterns of engagement, three countries were selected for investigation. Germany has had a stable majority of opponents to the deal and a high level of engagement, Sweden has had a stable majority supporting the agreement and a moderate level of engagement, while the UK has had a stable majority, but also a high level of engagement.

In each of the countries, two quality newspapers were chosen: Frankfurter Allgemeine Zeitung and Süddeutsche Zeitung (Germany); Svenska Dagbladet and
Aftonbladet (Sweden); and The Guardian and The Times (UK). Not only is there a greater likelihood that quality newspapers will feature EU actors in their coverage (de Vreese et al., 2006), but they are also generally seen as opinion leaders who are likely to influence other media outlets (Gattermann \& Vasilopoulou, 2015, p. 135). Furthermore, the newspapers are chosen to represent both sides of the left-right spectrum. Data was collected from June 2013, when the Council approved the mandate to open negotiations, until the end of December 2015. The sample includes all articles mentioning TTIP during that time period. Search words for Sweden were transatlantisk*, handelsavtal* and TTIP; for Germany TTIP and Freihandelsabkommen; and for the UK TTIP, transatlantic trade, EU AND trade. The EP passed two resolutions on TTIP, one in May 2013, just before the launch of the talks between the EU and the US, and one in July 2015, after 9 rounds of negotiations had taken place. Thus, plenary data is gathered from two occasions when the EP debated TTIP, focusing on interventions by MEPs from Germany, UK and Sweden (including explanations for votes; EP, 2013; EP, 2015b).

The article uses claims-making methodology to uncover the patterns of the debate and the MEPs' engagement and response. Claims-making methodology is a form of content analysis, where the analytical unit is the 'claim,' which basically means an actor statement that expresses for instance a political demand, criticism, proposals or calls to action (Statham \& Koopmans, 2009, p. 437). Different variables can be assigned to each claim, such as who is making the claim, when and where it is made, what the content of the claim is and to whom the claim is directed (Statham \& Koopmans, 2009). In this article, each claim was coded with country, newspaper and time period, then with who made the claim, the content of the claim, the object of the claim, to whom the claim was directed, and the type of justification for the claim.

To identify level of engagement, the focus was on who was making the claim, which allows a comparison between the total number of actors and the share of MEPs, over time. To study the type of responses offered by MEPs, three different codes were assigned if the claim i) contained a promise; ii) signals that the claimant was listening to particular concerns; iii) that reasons were given for the claim. An additional code was added if the justification explicitly evoked an audience, which signals to whom the explanation attempts to respond ${ }^{2}$. This is used as an indicator of attempts to mobilise and expand the scope of actors, i.e., efforts to politicise an issue. An additional code used to investigate how MEPs potentially contribute to politicisation, is to whom a claim is directed. This code indicates whether and how claims by MEPs seek to contest or change TTIP and the negotiations, including instances where opponents make claims towards supporters and vice versa. An example of such a claim is when British MEP, Molly Scott Cato (2015, Greens),

\footnotetext{
2 If a claim is made on behalf of someone, it can also be termed a 'representative claim' (de Wilde, 2013). This article, however, does not look at this aspect, but rather if an audience is evoked, signalling to whom someone is attempting to respond, and potentially also to mobilise.
} 
wrote: "This week hundreds of protesters against TTIP have descended on the European Parliament. They are quite rightly concerned about the threat that this treaty poses to the British government's ability to conduct its affairs in their interests."

The claims are compared quantitatively, but mainly qualitatively, in order to analyse degree of politicisation as well as if and how MEPs communicate with citizens and respond to their concerns.

\section{How Did MEPs Get Engaged in the Debate About TTIP?}

The following analysis first addresses the salience of the TTIP debate in all three countries. When studying media debates, one frequently used indicator of salience is the number of newspaper articles that is being written on the topic. In this article, although the reporting on the transatlantic trade negotiations are not compared with other issues (cf. Hoeglinger, 2016), comparing coverage of TTIP across time also gives an indication of change in salience.

Figure 1 shows the number of news articles that mention TTIP in Germany, Sweden and the UK, during the time period under study. In Germany there is a clear pattern of increasing attention to TTIP. Throughout 2013, the debate was almost completely dominated by the spying scandal. After documents released by Edward Snowden revealed that the Americans had been tapping into Angela Merkel's phone, a lot of actors demanded that the TTIP negotiations had to be stopped. Then from mid-2014 onwards there is a sharp increase in the number of articles. This coincides with the elections for the EP in the end of May, where the possibility of a free trade agreement between the EU and the US became a hot topic. After that, the overall reporting on TTIP in Germany remains on a high level although with a slight downward trend in 2015.

In Sweden, there is no steady pattern of rising salience as in Germany. The overall impression based on the coverage over time, is that the Swedish debate reflects a relatively low level of salience. Over time, the one spike in coverage is around the EP and general elections in May and September 2014 where TTIP became a contested topic among Swedish parties. Thus, despite low levels of salience, the news reporting is not dominated by surrogate reporting, as was for instance the case for the debate about the EU constitution (Trenz, Conrad, \& Rosén, 2009). The media debate in Sweden largely reflects national considerations regarding TTIP, rather than observing for instance the German debate. The results for the UK also reflect a lower level of salience. In 2013, the UK debate is mainly focused on the spying scandal in Germany. However, TTIP was increasingly put in a UK context in the run-up to the EP election in the spring of 2014, and even more so during the months around the UK general elections a year later. It was particularly the issue of the National Health Service (NHS) that instigated discussion-although there is a marked difference here between The Times and The Guardian, with the former seeming not to pay much attention to the NHS debacle.

Given these variations in salience between the different countries, the subsequent question is, how did MEPs engage in the evolving debates? Based on the expectations above, we would assume all MEPs to be more engaged than members of Parliament (MPs), but that MEPs in Germany have a lower level of engagement over time than in Sweden and the UK.

\subsection{Level of Engagement}

The set of conjectures delineated above all build on the assumption that MEPs are somehow receptive to citizens' concerns. Ripoll Servent's (2013) study of the EP's influence on the Data Retention Directive before and after the Lisbon Treaty, shows for instance that once a colegislator, the EP became more concerned about appearing as a responsible actor, rather than pushing for its own agenda. Furthermore, trade policy may also trigger particular national interests, which means that MEPs have to adjudicate between their commitments to their national party, to their EU party group, as well as to their voters. This may have a form of silencing effect that discourages them from participating in debates on TTIP. However, this does not seem to be the case for TTIP-at least not for the MEPs as a whole. Although the share of MEPs in the

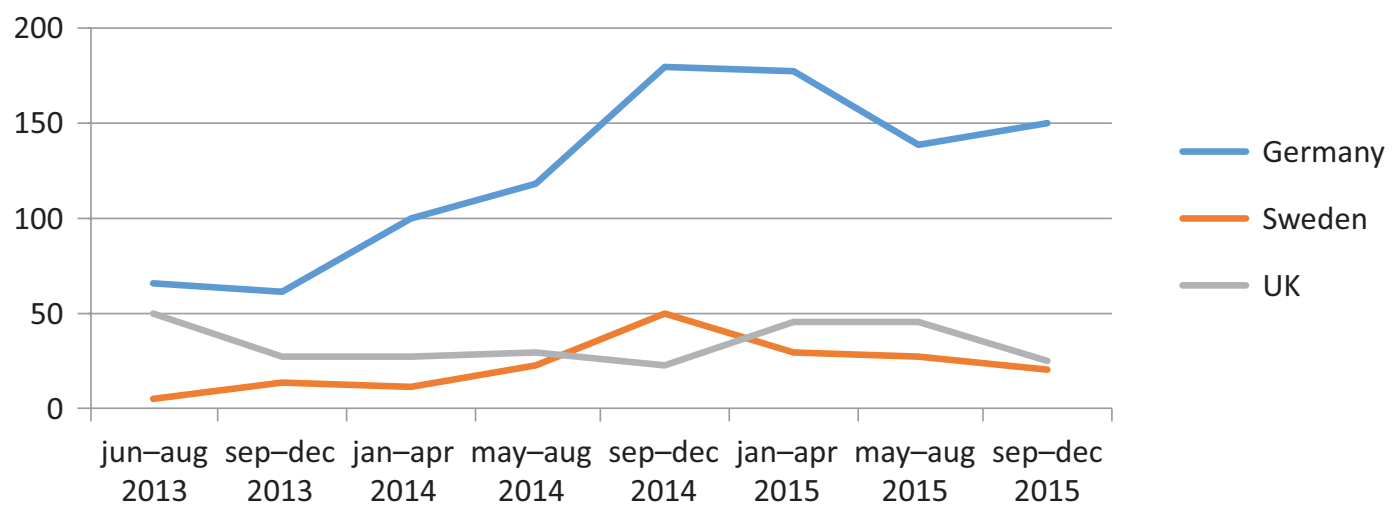

Figure 1. Number of articles on TTIP. Note: Total $=1444$. 


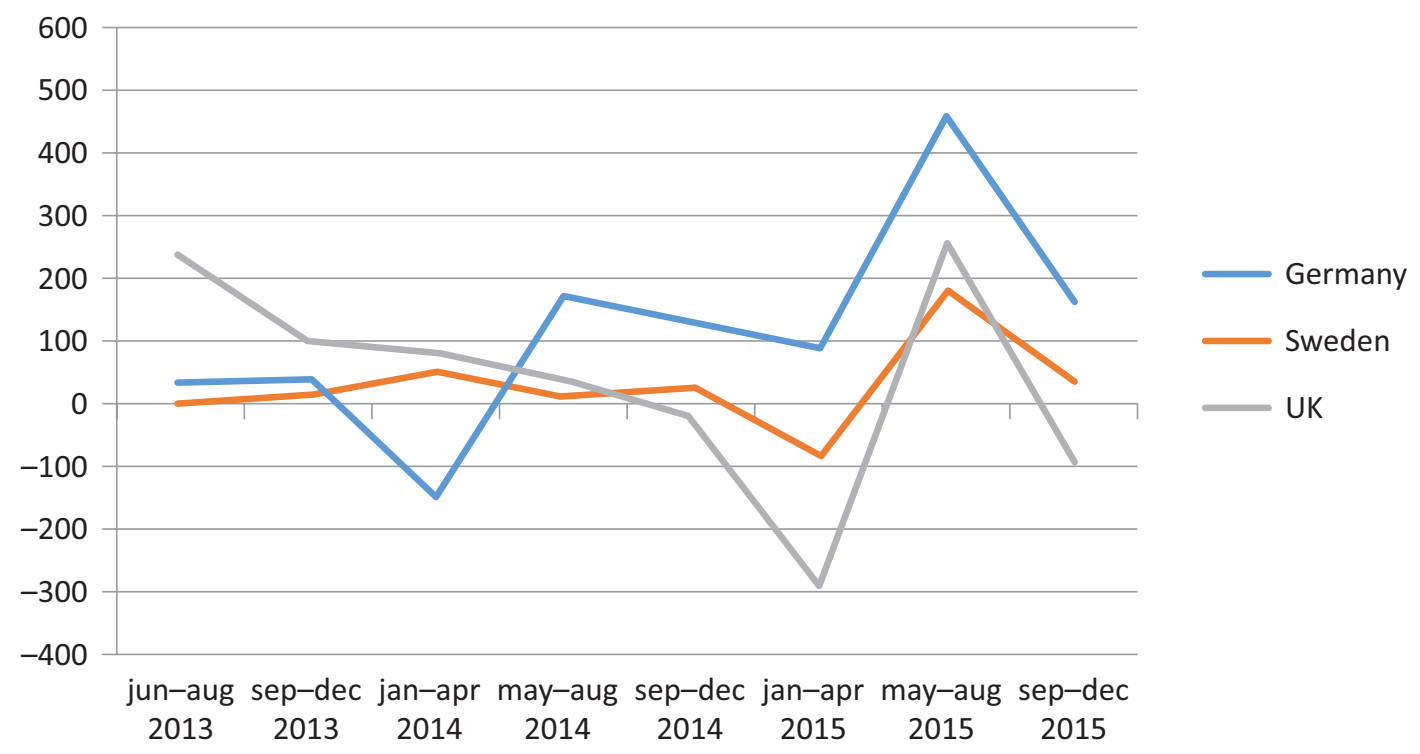

Figure 2. Engagement of MEPs relative to MPs. Note: The number of claims made by MEPs and MPs are weighted according to the share of articles published.

total sample of media debates is moderate with around $11 \%$ of the claims made by MEPs, they do feature regularly in the newspaper coverage. In Sweden for example, over half of the non-executive actors in Swedish media debates are MEPs; MPs or other representatives of political parties ${ }^{3}$.

Another way of analysing the engagement of MEPs is to compare their visibility to that of national MPs. A main assumption of this article is that TTIP is an occasion for MEPs to demonstrate their value to the EU citizenry. If that were the case, one would expect MEPs not only to engage in public debates, but also that they are more engaged than national MPs, which can be taken as an indicator that MEPs take a lead in the TTIP debate-also at the national level. Thus, the figure above shows how MEPs feature in the sample, relative to MPs.

In all three countries there are more claims made by MEPs than by MPs under the period of June 2013 through December 2015. Although there are some fluctuations over time, the predominant pattern is that MEPs feature more than MPs. This testifies to the assumption that TTIP is an issue where MEPs assume ownership. It is important to note here that the media also give voice to EU parliamentarians outside of their own country. Both British and Swedish newspapers covered the controversies Germany extensively. In the UK, for example, most MEPs found in the sample from 2013 are not British, but German MEPs speaking out against the spying scandal. Several of the claims made by Swedish MEPs stem from op-eds. A string of contributions by MEPs discussed back and forth the transparency of the negotiations as well as controversial issues such as the ISDS mechanism. Especially around the time of the EP elections in the spring of 2014, TTIP was a frequent topic, whilst the months after were characterised more by reactions to events taking place at the EU level, e.g., the July 2015 vote in the EP. Once the British debate turned its focus inwards towards the middle of the time period, British MEPs become more visible, but so do British MPs, who not only dominated the debate about NHS, but also started mobilising around TTIP, especially in the period around the general elections with some Labour members taking a very strong stand against the EU-US deal. According to The Times (Hopkins, 2015), then shadow chancellor John McDonell said TTIP would "allow corporations 'to steal' from ordinary people."

Looking only at claims made by MEPs, in Sweden, the percentage of the total number of claims is around $20 \%$ compared to around $8 \%$ in Germany, but the total number of claims made by MEPs in Germany is higher, which is unsurprising given the amount of coverage in the German press. At the same time, while the number of claims by MEPs in Sweden drop immediately after the EP has gone forward with its vote in July 2015, German MEPs remain active throughout the period under study. This calls into question the expectation that MEPs in countries with increasing issue salience have a lower level of engagement. The autumn of 2015 was a period where the German public was mobilising strongly against TTIP, with a lot of demonstrations and community meetings taking place. German MEPs might be waking up to the fact that they need to somehow react to the massive resistance towards the agreement in Germany. Summing up, although the numbers are rather small, these patterns not only refute the suggestion that MEPs do not engage in media debates, but also indicate that parliamentarians at the EU level are taking the lead in the TTIP debate. Moreover, there is little evidence of a silenc-

\footnotetext{
${ }^{3}$ By comparison, national governments-whilst clearly pro-TTIP-were not very active, but Trade Commissioner Malmström was highly visible in the Swedish debate from the time her candidacy was announced at the end of the summer of 2014.
} 
ing effect, potentially resulting from the cross-pressure MEPs are facing (again, it has to be underlined that finding only holds for MEPs as a whole. The silencing effect could be more prevalent for some parties than others. However, the data used in this article is too small to gauge this properly). Being visible, however, is not the same as being responsive. Thus, the subsequent question is what characterises MEPs' engagement.

\subsection{Responsiveness}

Following the expectation that issue salience generates more substantial responses by MEPs, we would presume that German MEPs are more likely to offer explanations and promises compared to the Swedish and British MEPs, particularly from 2014 onwards when issue salience increases.

Many claims by Swedish MEPs contain explanations. For example, when arguing for the soundness of the ISDS mechanism. MEP Christofer Fjellner (2013), from the EPP group, refers to Sweden's many similar investment agreements, and argues that such a mechanism is not about undermining democracy, but about securing respect for basic legal principles. By contrast, it is very uncommon for MEPs to signal that they are listening to people's concerns, and also few promises are made.

In the UK, throughout most of 2013 it is the German spying scandal and its potential effects on the TTIP talks that dominate, and most of the parliamentarians featured in these articles are from the EP or Germanynot British. Towards the end of the year and in the period leading up to the EP elections, more MEPs enter the scene, but still-at least in the TTIP contextthere are fewer claims by British MEPs compared to other European countries. This indicates support for Gatterman and Vasilopoulo's (2015) finding that British MEPs get little coverage. Instead, as described above, British MPs took centre stage as the TTIP debate got entangled with national party politics. In December 2014, the Home Affairs Committee questioned Theresa May about the NHS and other committees issued reports on TTIP during 2015. Compared to Germany and Sweden, and although MEPs dominate in the whole sample, more MPs are visible in the UK coverage around the general elections in May 2015, when Cameron's plans for negotiating a new deal with the EU came on the agenda. When the NHS is the topic, there are examples of several responsive claims, such as Andy Burnham promising that his Labour government would exempt NHS from TTIP (Jones, 2014). The pressure on the British government increased throughout 2015, starting with a debate in the House of Commons in mid-January, where MPs voiced their concerns over various aspects of the deal such as the ISDS mechanism and food safety. All claims contain explicit justifications for positions voiced and are as such responsive.

Almost immediately after the launch of the negotiations in June 2013, the news about the US spying on
Germany broke, and several German MEPs replied by demanding to freeze the TTIP negotiations. This demand dominates almost all claims made by MEPs in the sample from 2013 as well as the first half of 2014. From then on, MEPs focus more on the negotiations and content of the EU-US deal. However, there is little to suggest that MEPs in Germany, where salience has been increasing, have a higher propensity to respond in a particular manner. The claims made by German MEPs do not differ much from those of their British and Swedish colleagues. Promises to adapt and signalling that they are listening are rare, whereas explanations are prevalent.

Although promises might be slightly more prevalent during the period when there was a spike in attention to TTIP in the British newspapers, the Swedish example showed that also Swedish MEPs tend to give explanations for their positions, regardless of the level of salience. This pattern is also characteristic of the German debate, suggesting that issue salience is not necessary for MEPs to justify their positions. With regards to promises made, there is perhaps a small indication of a stronger relationship, but the numbers are too small to conclude. Whether they justify their claim with reference to public opinion and public concerns-i.e., are explicit about who they respond to-also varies a lot, both across the three countries and over time. However, one trait is recurrent in all three countries: While most MEPs might refer to public opinion on occasion, opponents of TTIP are more likely to do so, throughout the time period. They also use public interest to contest the agreement. For example, in an op-ed MEP Malin Björk (2015, European United Left-Nordic Green Left [GUE/NGL]), together with colleagues from the Swedish parliament, states:

The Swedish Government must now say what they think. Should citizens, democracy, climate and labour law go first, or big business? The Left party demands that the EU Commission and the government take seriously the legitimate concerns of the critics of the TTIP agreement.

Thus, the subsequent question is, whether and how MEPs make claims that seek to contribute to politicisation.

\subsection{Contribution to Politicisation}

What we expect is that MEPs seek to contribute to politicisation when issue salience increases by attempting to expand the scope of conflict through evoking a larger set of actors and contesting the agreement. Thus, we expect that German MEPs are more likely to contribute to politicisation, due to the higher level of salience in the national media.

When Swedish parliamentarians respond to conflicting viewpoints, they are mainly directed at opposing political parties. One MEP candidate from the Leftist 
Vänsterpartiet, for example, accused the government coalition of putting "the interest of big business before food, environment and even democracy" (Björk, 2014). Following the general elections in September 2014, MEP Fjellner (2014) from the outgoing governmental party Moderaterna expressed his "genuine worry" about Sweden's position as a free trade nation with a new social democratic government in office. While subject to party competition, TTIP did not seem to gain much traction in the general public. In fact, a Eurobarometer from November 2016 showed that at the time support for TTIP among Swedish citizens was actually increasing (European Commission, 2016). To the extent that they respond to public concerns in combination with a claim for or against a given policy, this is more or less exclusive to parties opposing TTIP, who refer to public opinion in order to justify their demands for changing or stopping the agreement. Still, a lot of the Swedish claims are directed at political opponents, meaning that they contribute to politicise the debate. To a certain extent, one could say that the Swedish debate resembles what Zimmermann (2019) calls "layered" politicisation. Political actors contest each other's positions, and some also attempt to mobilise a larger set of actors, but the level of salience remains relatively low throughout the time period.

In the UK, the party conflict appears to be lower on TTIP, perhaps because the debate is also conducted in the shadow of Brexit. With NHS, contestation increases, but there are still not a lot of examples of claims that are explicit about the audience to which it responds, nor are there many claims that use public opinion to contest the agreement. Taking into account that the numbers are too small to draw firm conclusions, MEPs also take part in the debate, echoing the concerns of opponents of the deal. As mentioned by Molly Scott Cato (2015, MEP, Greens): "This week hundreds of protesters against TTIP have descended on the European Parliament. They are quite rightly concerned about the threat that this treaty poses to the British government's ability to conduct its affairs in their interests." Only in the case of the NHS, however, do such claims appear to be accompanied by a spike in issue salience.

From 2015 onwards, corresponding to increasing salience, more responses that refer explicitly to people's concerns also ask for moderation. MP Adrian Bailey (Labour), for example, was cited by The Guardian calling for a more informed discussion: "Campaigners, lobbyists, business groups, government and the European Commission also need to do more to engage with the evidence rather than make unsupported claims about the benefits or risks of TTIP" (Elliot, 2015). Similar examples can be found in the discussion over ISDS in Sweden. Like their British and Swedish colleagues, those who support TTIP attempt to temper criticism: "The Germans fear being swept away by the Americans, which expresses a lack of self-confidence" (MEP Elmar Brok [EPP], 2015). Others express their understanding that people worry when they do not know what is being negotiated, going on to assure: "We do not want to lower our high standards in Europe, such as food and healthcare. We do not want to allow intervention in local self-government" (MEP Angela Niebler [EPP], 2015). These can be seen as examples of claims that are responsive, but also that attempt to de-politicise the debate, i.e., trying to contain conflict rather than amplify it. Thus, a pattern emerges of across the three countries of supporters of TTIP aiming to de-politicise the debate by refuting criticism, i.e., by responding to people's concerns they attempt to alleviate contestation.

Still, the data material displays a greater tendency also among those who support TTIP to be more specific about red lines and demands to the Commission and/or government midway into the period under study, which is when the salience of TTIP increased. In Sweden, although one must keep in mind that the numbers are small, there are few examples of supporters staking their claims in a similar manner, at least in the media sample, but in the UK there are signs of a comparable development, particularly on the issue of the NHS. This potentially has a different effect compared to the explicit efforts to de-politicise the debate, because it amplifies contestation.

Swedish MEPs wrote several op-eds on TTIP, which would allow them to choose how to approach readers. Nevertheless, journalists may act as filters on some forms of claims, discarding responsive statements, because it does not quite fit their story. During plenary debates MEPs are able to shape their own message in full. Looking at the plenary debates on TTIP in the EP from 2013 and 2015, confirms the tendency of parliamentarians becoming more specific on their conditions for support of the deal.

In 2013, MEP Bernd Lange from the Progressive Alliance of Socialists and Democrats explains his group's support for TTIP on economic grounds, while indicating some apprehension about the negotiation partner's standards (EP, 2013). TTIP supporter Daniel Caspary's (EPP) interventions clearly reflect that he does not see a great need to engage with voters' concerns. Instead he argues that most Germans trust politicians to manage trade politics, and that "a large part of the citizens in Europe just do not want to deal with such topics" (EP, 2013). In line with the media data, only the opponents to TTIP are clear on whose behalf they are taking a stand. An intervention by MEP Scholz (GUE/NGL), for example, explicitly refers to specific "worries of the people," and that his party group assesses every agreement according to the interest of the people (EP, 2013). This is a clear example of a claim where he not only justifies his position, but also signals that the he listens to people's concerns and makes the promise that his party will reject any deal that do not meet these key points.

During the plenary debate two years later, the situation is different (EP, 2015b). The opponents of TTIP are not the only ones taking contingent positions. Elmar Brok (EPP) declares: "no lowering of standards!", while 
his colleague, Angelika Niebler, promises to make it clear to the Americans "what cannot be done with us Europeans" (EP, 2015b). Several similar responsive claims are found among the British MEPs across the political spectrum. Many of these claims also evoke public opinion. Joachim Schuster (Progressive Alliance of Socialists and Democrats), for example, states that they have succeeded in picking up many of the issues that have been discussed in public and translated them into conditions to the Commission. MEP Cecilia Wikström (Alliance of Liberals and Democrats for Europe group), in defending her vote for TTIP, makes a promise to "the thousands of citizens of Sweden" who have contacted her that "the norms and values we safeguard in the EU should in no way be sacrificed or lowered through TTIP" nor will "[p]roducts that do not meet EU high standards" be approved in the European market (EP, 2015b). Moreover, there clearly is a difference between the debates in 2013 and 2015, with the overwhelming majority of MEPs offering explanations for their positions.

\section{Concluding Discussion}

The analysis of the TTIP debate in Germany, Sweden and the UK showed differences in issue salience. Germany experienced increasing issue salience throughout the time period. In Sweden and the UK, TTIP was not nearly as salient, albeit with spikes of attention around the EP and national elections. The expectation that MEPs were more engaged than MPs received some support, which testifies to the assumption that TTIP was an occasion where they could take ownership of an issue. However, the example of the UK shows that when an EU matter gets entangled with an issue that is sensitive to national politics, such as the NHS, MPs become active and MEPs take the backstage. With the new generation of free trade agreements that increasingly go behind border addressing national regulations, MEPs might still face significant competition from national MPs if and when a trade agreement spurs debate about policy issues that hit close to home, as with the NHS in the UK.

The expectation that more MEPs tend to offer promises and explanations with increasing salience also needs additional qualification. Issue salience appears to be neither necessary nor sufficient to generate claims that contain promises or explanations. There are several factors that could incite MEPs to make responsive claims. The example of Sweden illustrates this where the debate about TTIP is characterised by marked party competition throughout the time period. Furthermore, there might also be factors that dissuade responsive behaviour. There is little evidence in the data that higher levels of salience lead to less engagement by MEPs. However, this is the case for all MEPs, whereas there might be differences between parties that are beyond the emphasis of this article.

Another question is what precisely MEPs are responding to. Issue salience is only one component of the broader phenomenon of politicisation, and it could be that polarisation would provoke different reactions. Furthermore, de Bruycker (2017) has shown that issue salience and mobilisation of civil society actors caused elites to refer to public interests more often. This article has focused on issue salience, however, because an aim was to see how MEPs contributed to politicise TTIP. The fear that EP empowerment would contribute to politicise EU trade policy receives ambivalent backing. A consistent finding is that the opponents of TTIP most frequently evoke the 'voice of the people,' regardless of level of issue salience. This is a finding that cuts across all three countries as well as time. Supporters, however, tried to de-politicise the debate and contain conflict. Nevertheless, because increasing issue salience seems to coincide with making demands for support, supporters as well might contribute to expanding the scope of the conflict over TTIP.

Two implications of these findings deserve a more detailed discussion. First, they demonstrate the multifaceted relationship between responsiveness and politicisation. Parliamentarians use responsive claims to demonstrate that they react to specific public concerns, but also to draw attention to their own position and mobilise the public when combined with a claim directed against other actors. In other words, parliamentarians not only react to politicisation, they also attempt to make politicisation happen by evoking public opinion. However, responsiveness can also be used in a depoliticising manner, as the statements from several supporters of TTIP show. Such claims contain a form of communicative response, e.g., an explanation, whilst also evoking a specific public opinion, but without an accompanying claim for a change of policy. Uncovering the pattern of claims that serve these contradictory purposes, and the conditions under which claims-making contributes to politicisation or de-politicisation should be the topic of future studies.

Secondly, there is a growing literature on how politicians (and non-elected) use claims to convince voters of their eminence as representatives (e.g., de Wilde, 2013). The question is how the degree and type of responsiveness is part of such efforts to establish a representative relationship. The aim of this article was to begin to explore how responsiveness feature in representative claims-making. Future research should do this more systematically using larger data, in order to uncover the conditions under which parliamentarians act responsively in various ways. While policy responsiveness is the ultimate evidence that citizens' interests are taken into account, communicative responsiveness, as has been the focus of this article, is of key importance to the maintenance of representative processes. In order to increase our understanding of the workings of our representative political systems, we should continue our study of how parliamentarians communicate to and with those they claim to represent. 


\section{Acknowledgments}

Previous versions of this article have been presented at conferences where several people have provided insightful and much appreciated feedback. I would also like to thank Christine Neuhold and the three anonymous reviewers for valuable and constructive comments and suggestions. The research for this article is funded by the Norwegian Research Council through a FRIPRO Mobility Grant, project number: 240845.

\section{Conflict of Interests}

The author declares no conflict of interests.

\section{References}

Adam, S., \& Maier, M. (2011). National parties as politicizers of EU integration? Party campaign communication in the run-up to the 2009 European Parliament election. European Union Politics, 12(3), 431-453.

Auel, K., Rozenberg, O., \& Tacea, A. (2015). To scrutinise or not to scrutinise? Explaining variation in EUrelated activities in national parliaments. West European Politics, 38(2), 282-304.

Bartels, L. M. (1991). Constituency opinion and congressional policy making: The Reagan defense build up. American Political Science Review, 85(2), 457-474.

Baumann, M., Debus, M., \& Gross, M. (2019). Strategic issue emphasis in parties' election campaign statements. Party Politics. Advance online publication. https://doi.org/10.1177/1354068819864091

Bellamy, R., \& Kröger, S. (2016). The politicisation of European integration: National parliaments and the democratic disconnect. Comparative European Politics, 14(2), 125-130.

Björk, M. (2014, May 20). Så säger EU-topparna om danska fläsket [Here's what EU top politicians say about Danish pork]. Aftonbladet.

Björk, M. (2015, April 23). Låt demokratin gå före storföretagen [Let democracy go before big corporations]. Aftonbladet.

Brok, E. (2015, March 9). Risse im Beziehungsfundament [Cracks in the relationship's foundation]. Süddeutsche Zeitung.

Bølstad, J. (2015). Dynamics of European integration: Public opinion in the core and periphery. European Union Politics, 16(1), 217-220.

Budge, I. (2015). Issue emphases, saliency theory and issue ownership: A historical and conceptual analysis. West European Politics, 38(4), 761-777.

Burns, C., \& Carter, N. (2010). Is co-decision good for the environment? An analysis of the European Parliament's green credentials. Political Studies, 58(1), 123-142.

Cato, M. S. (2015, February 4). I've seen the secrets of TTIP, and it is built for corporations not citizens. The Guardian.
Coremans, E., \& Meissner, K. (2018). Putting power into practice: Administrative and political capacity building in the European Parliament's commitee for international trade. Public Adminsitration, 96(3), 561-577.

da Conceição-Heldt, E., \& Meunier, S. (2014). Speaking with a single voice: Internal cohesiveness and external effectiveness of the EU in global governance. Journal of European Public Policy, 21(7), 961-979.

de Bruycker, I. (2017). Politicisation and the public interest: When do the elites in Brussels address public interests in EU policy debates? European Union Politics, 18(4), 603-619.

de Ville, F., \& Siles-Brügge, G. (2015). The truth about the transatlantic trade and investment partnership. Cambridge: Polity Press.

de Vreese, C. H., Banducci, S. A., Semetko, H. A., \& Boomgaarden, H. G. (2006). The news coverage of the 2004 European Parliamentary election campaign in 25 countries. European Union Politics, 7(4), 477-504.

de Wilde, P. (2011). No polity for old politics? A framework for analyzing the politicization of European integration. Journal of European Integration, 33(5), 559-575.

de Wilde, P. (2013). Representative claims analysis: Theory meets method. Journal of European Public Policy, 20(2), 278-94.

Dür, A., \& Mateo, G. (2014). Public opinion and interest group influence: How citizen groups derailed the anticounterfeiting trade agreement. Journal of European Public Policy, 21(8), 1199-1217.

Elliot, L. (2015, March 25). MPs denounce government TTIP plans amidst NHS and public services. The Guardian.

Esaiasson, P., Gilljam, M., \& Persson, M. (2013). Communicative responsiveness and other central concepts in between-election democracy. In P. Esaiasson \& H.-M. Narud (Eds.), Between-election democracy: The representative relationship after election day (pp. 15-33). Colchester: ECPR Press.

Esaiasson, P., Gilljam, M., \& Persson, M. (2017). Responsiveness beyond policy satisfaction: Does it matter to citizens? Comparative Political Studies, 50(6), 739-765.

Esaiasson, P., \& Narud, H. M. (Eds.). (2013). Betweenelection democracy. The representative relationship after election day. Colchester: ECPR Press.

European Commission. (2014). Standard Eurobarometer Survey No. 82. Retrieved from https://ec.europa.eu/ commfrontoffice/publicopinion/index.cfm/Survey/ getSurveyDetail/instruments/STANDARD/surveyKy/ 2041

European Commission. (2015). Standard Eurobarometer Survey No. 84. Retrieved from https://ec.europa.eu/ commfrontoffice/publicopinion/index.cfm/Survey/ getSurveyDetail/instruments/STANDARD/surveyKy/ 2098

European Commission. (2016). Standard Eurobarometer 
Survey No. 86. Retrieved from https://ec.europa.eu/ commfrontoffice/publicopinion/index.cfm/Survey/ getSurveyDetail/instruments/STANDARD/surveyKy/ 2137

European Parliament. (2013). EU trade and investment agreement negotiations with the US (debate) (PV 22/05/2013-17). Brussels: European Parliament. Retrieved from http://www.europarl.europa. eu/sides/getDoc.do?type=PV\&reference $=20130522$ \&secondRef=ITEM-017\&language=EN\&ring=B72013-0187

European Parliament. (2015a). European Parliament resolution of 8 July 2015 containing the European Parliament's recommendations to the European Commission on the negotiations for the Transatlantic Trade and Investment Partnership (TTIP) (2014/2228[INI]). Brussels: European Parliament. Retrieved from http://www.europarl.europa.eu/ doceo/document/TA-8-2015-0252_EN.html

European Parliament. (2015b). Negotiations for the Transatlantic Trade and Investment Partnership (TTIP) (debate) (PV 07/07/2015-4). Brussels: European Parliament. Retrieved from http://www. europarl.europa.eu/doceo/document/PV-8-201507-07-ITM-004_EN.html?redirect

Fjellner, C. (2013, November 21). MP har plockat fram gamla konspirationsteorier [MP has brought up old conspiracy theories]. Svenska Dagbladet.

Fjellner, C. (2014, September 16). Nygammalt Sverige väntar i EU [New old Sweden is waiting in the EU]. Aftonbladet.

Gattermann, K. (2013). News about the European Parliament: Patterns and external drivers of broadsheet coverage. European Union Politics, 14(3), 436-457.

Gattermann, K., \& Vasilopoulou, S. (2015). Absent yet popular? Explaining news visibility of members of the European Parliament. European Journal of Political Research, 54(1), 121-140.

Gheyle, N. (2019a). Conceptualizing the parliamentarization and politicisation of European Politics. Politics and Governance, 7(3), 227-236.

Gheyle, N. (2019b). Trade policy with the lights on. The origins, dynamics, and consequences of the politicisation of TTIP (Unpublished Doctoral dissertation). Ghent University, Belgium.

Green-Pedersen, C. (2012). A giant fast asleep? Party incentives and the politicisation of European integration. Political Studies, 60(1), 115-130.

Grose, C., Malhotra, N., \& Van Houweling, R. P. (2015). Explaining explanations: How legislators explain their policy positions and how citizens react. American Political Science Journal, 59(3), 724-743.

Hix, S. (2002). Parliamentary behavior with two principals: Preferences, parties, and voting in the European Parliament. American Journal of Political Science, 46(3), 668-698.

Hix, S., Noury, A., \& Roland, G. (2007). Democratic politics in the European Parliament. Cambridge: Cam- bridge University Press.

Hix, S., Raunio, T., \& Scully, R. (2003). Fifty years on: Research on the European Parliament. Journal of Common Market Studies, 41(2), 191-202.

Hobolt, S. B., \& Klemmensen, R. (2008). Government responsiveness and political competition in comparative perspective. Comparative Political Studies, 41(3), 309-337.

Hoeglinger, D. (2016). The politicisation of European integration in domestic election campaigns. West European Politics, 39(1), 44-63.

Hooghe, L., \& Marks, G. (2009). A postfunctionalist theory of European integration: From permissive consensus to constraining dissensus. British Journal of Political Science, 39(1), 1-23.

Hopkins, K. (2015, October 12). Labour leads calls against trade pact. The Times.

Hutter, S., \& Grande, E. (2014). Politicizing Europe in the national electoral arena: A comparative analysis of five West European countries, 1970-2010. Journal of Common Market Studies, 52(5), 1002-1018.

Jones, O. (2014, September 14). The TTIP deal hands British sovereignty to multinationals. The Guardian.

Lord, C. (2013). No representation without justification? Appraising standards of justification in European Parliament debates. Journal of European Public Policy, 20(2), 243-259.

Manin, B., Przeworski, A., \& Stokes, S. (1999). Introduction. In A. Przeworski, S. Stokes, \& B. Manin (Eds.), Democracy, accountability and representation (pp. 1-26). Cambridge: Cambridge University Press.

Meissner, K. (2016). Democratizing EU External relations: The European Parliament's informal role in SWIFT, ACTA, and TTIP. European Foreign Affairs Review, 21(2), 269-288.

Mühlböck, M. (2012). National versus European: Party control over members of the European Parliament. West European Politics, 35(3), 607-631.

Niebler, N. (2015, November 6). Europa ist nicht nur eine Cash-Maschine [Europe is not just a cash-machine]. Süddeutsche Zeitung.

Niemann, A. (2011). Conceptualising common commercial policy treaty revision: Explaining stagnancy and dynamics from the Amsterdam IGC to the Treaty of Lisbon (European Integration Online Papers Vol. 15 [2011], Article 6). Retrieved from http://eiop.or.at/ eiop/texte/2011-006a.htm

Pitkin, H. F. (1967). The concept of representation. Berkeley, CA: University of California Press.

Rauh, C. (2019). EU politicisation and policy initiatives of the European Commission: The case of consumer policy. Journal of European Public Policy, 26(3), 344-365.

Raunio, T. (2000). Losing independence or finally gaining recognition? Contacts between MEPs and national parties. Party Politics, 6(2), 211-223.

Ripoll Servent, A. (2013). Holding the European Parliament responsible: Policy shift in the data retention 
directive from consultation to codecision. Journal of European Public Policy, 20(7), 972-987.

Rosén, G. (2018). Contestation and co-optation: Why secrecy in EU external relations varies. West European Politics, 41(4), 933-957.

Statham, P., \& Koopmans, R. (2009). Political party contestation over Europe in the mass media: Who criticizes Europe, how, and why? European Political Science Review, 1(3), 435-463.

Statham, P., \& Trenz, H. J. (2015). Understanding the mechanisms of EU politicisation: Lessons from the Eurozone crisis. Comparative European Politics, 13(3), 287-306.

Toshkov, D. (2011). Public opinion and policy output in the European Union: A lost relationship. European Union Politics, 12(2), 169-191.

Trenz, H.-J., Conrad, M., \& Rosén, G. (2009). Impartial mediator or critical watchdog? The role of political jour- nalism in EU constitution-making. Comparative European Politics, 7(3), 342-363.

Wlezien, C., \& Soroka, S. (2012). Political institutions and the opinion-policy link. West European Politics, 35(6), 1407-1432.

Woolcock, S. (2008). The potential impact of the Lisbon Treaty on European Union external trade policy. Stockholm: Swedish Institute for European Policy Studies.

Young, A. (2019). Two wrongs make a right? The politicisation of trade policy and European trade strategy (Working paper GTJMCE-2019-1) Atlanta, GA: Sam Nunn School of International Affairs, Georgia Institute of Technology.

Zimmermann, H. (2019). The European Parliament and the layered politicisation of the external dimension of the common fisheries policy. Politics and Governance, $7(3), 237-247$.

\section{About the Author}

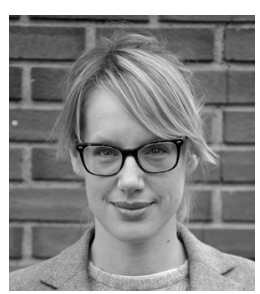

Guri Rosén is Researcher at ARENA Center for European Studies, University of Oslo. Her research focuses on the EP, EU external relations, interinstitutional relations, political representation and democracy in the EU. Her work has been published in journals such as Journal of European Public Policy, West European Politics, and Journal of European Integration. 